\title{
Structural Equations Modeling, Perceived Risk and Flow State on E-Commerce
}

\author{
Cristiane Salome Ribeiro Costa ${ }^{1}$, Rafael Lucian ${ }^{2}$ \\ ${ }^{1}$ Centro Academico do Agreste, Universidade Federal de Pernambuco, Caruaru, Brasil \\ ${ }^{2}$ Mestrado Profissional em Gestão Empresarial, Faculdade Boa Viagem, DeVry Brasil, Recife, Brasil \\ Email: csrcosta@yahoo.com.br, rlucian@fbv.edu.br
}

Received 16 January 2014; revised 16 April 2014; accepted 9 May 2014

Copyright (C) 2014 by authors and Scientific Research Publishing Inc.

This work is licensed under the Creative Commons Attribution International License (CC BY). http://creativecommons.org/licenses/by/4.0/

(c) (i) Open Access

\begin{abstract}
Flow state is an important theory to understand the consumer behavior of e-commerce. Perceived risk also has been object of academic studies because it is an inhibitor of the online purchases. In this way, the objective of this research is to investigate the relation between the perceived risk and flow state. Through a structural equations modeling, it was disclosed that the ability of the consumer with the use of the Internet intervenes with its perception of risk.
\end{abstract}

\section{Keywords}

\section{Structural Equations Modeling, Perceived Risk, Flow State, E-Commerce}

\section{Introduction}

The researcher's interest about online consumer behavior is growing [1]. This attention is resulted of the increase in the electronic commerce sales [2]. The main advantage of e-commerce is the comfort, including easiness and agility in the search of information and meeting of the amount of certain information in a lesser time $[3]$.

It is important that the virtual companies know how to attract and to conquer the individuals during purchases on-line. Understanding flow theory is an important active to manage an online environment.

Csikszentmihalyi [4] defines flow state as an excellent experience of been completed evolved in the activity of purchase. Hoffman and Novak [5] suggest an important objective for marketing specialists to provide these emotions.

However, consumers may perceive several risks in the interaction between them and the machines (computer) [6]. Smith and Sivakumar [6] indicate that the risk can influence the flow state positively. It occurs because of the challenges identification and individual abilities needed during the online purchase process. 
Once Smith and Sivakumar [6] have just proposed without empirical test the correlation between flow state and perceived risk, this study will test this hypothesis.

The next item presents the theoretical revision of this study.

\section{E-Commerce, Perceived Risk and Flow State}

Online purchases can unchain some new types of risks, per example, the risk of the privacy and the transmitted information security [7] and the impossibility to analyze the product physically [8]. Rohm and Milne [9] suggest that the biggest part of the Internet users has concerns regarding to the privacy of its information.

Time is another risk that occurs in Internet purchase. Consumers must wait the delivery time to receive the product and if the consumer receive a wrong product he has just waste his time [3].

Perceived risk is not the only existing subject in the literature that helps to understand the behavior of the consumer in the Internet. Flow is another theory that is growing in marketing studies.

According Hoffman and Novak [5] the flow state occurs when the Internet purchases have the follow dimensions: interactivity, telepresence, ability, control, challenge, activation and focused attention.

Interactivity is the easiness to use the website. Novak, Hoffman and Yung [10] had identified that the interatividade is defined as the speed with the site answers the consumers actions.

Telepresence occurs when the consumer fells the virtual word (website) as a physical world [11]. Hoffman and Novak [5] affirm that the ability level of the consumer with the Internet can lead to the experience of flow state. Ability refers to the knowledge about the navigation tools.

There are three more dimensions; the challenge and arousal, both regarding to the attitude of the costumer and the attention focus [4].

When the consumer is concentrated in the activity, it loses the time notion and all the irrelevant thoughts are disrespected, taking the individual to the loss of conscience, of notion of space and time [10].

Our objective in this paper is to understand the relation between the perception of risk and the state of flow considering previous studies as of Smith and Sivakumar [6].

Smith and Sivakumar [6] suggest that the risk perception contributes for the flow state occurrence.

In the first purchase, the existence of the risk takes the individual to be more intent in the hour of the purchase leading to the experience of flow state. The experience with the online purchase makes the individual to have a bigger ability and low sensation of challenge, being diminished the risk perception and reducing the possibility of the consumer to experience the flow [12].

Regarding to repeated purchases by Internet, Mathwick and Rigdon [13] understand that a low perceived risk inhibits the occurrence of the flow state because the increase in the use of the Internet provides a high ability and a consequent feeling of annoyance.

Based on literature, we understand that it is important to test empirically if there is any relationship between perceived risk and flow state. Our researches hypotheses are presented in Table 1.

\section{Method}

This study has a descriptive characteristic [16]. Our objective was to identify if there is a relation between the perceived risk and the flow state. Sample of this study was composed by 196 respondents with at least 18 years old that has been purchasing on Internet for at least six months. This sample is above of the ideal number of 100 respondents considered by Hair et al. [17] for the multivaried data analyses.

The questionnaire was composed by: Likert scale to measure perceived risk and flow state and semantic differential scale to measure the flow dimensions [16]. Table 2 presented the used scales:

Next topic explains the analysis procedures.

Table 1. Hypotheses.

\begin{tabular}{|c|c|c|}
\hline & Hypotheses & Source \\
\hline H1 & $\begin{array}{l}\text { Perceived Risk is correlated } \\
\text { with consumer ability on e-commerce. }\end{array}$ & $\begin{array}{c}\text { Koufaris [1], Bhatnagar and Ghose Bhatnagar and Ghose (2004), } \\
\text { Doolin et al. Doolin et al. }(2005)\end{array}$ \\
\hline $\mathrm{H} 2$ & $\begin{array}{l}\text { High risk perception on } \\
\text { e-commerce leads to flow state. }\end{array}$ & $\begin{array}{l}\text { Dailey Dailey (2004), Delespaul et al. Delespaul et al. (2004), Mathwick and Rigdon } \\
\text { Mathwick and Rigdon (1998), Smith and Sivakumar Smith and Sivakumar (2002). }\end{array}$ \\
\hline
\end{tabular}


Table 2. Scales.

\begin{tabular}{cccc}
\hline Theory & $\mathrm{N}^{\circ}$ Items & Scale Used & Source \\
\hline Perceived Risk & 8 & Likert & Kovacs and Farias Kovacs and Farias (2005) \\
Flow State & 12 & Semantic Differential & \\
Flow Dimension (ability) & 20 & Likert & Novack, Hoffman and Yung Novak et al. (2000) \\
\hline
\end{tabular}

\section{Data Analysis}

The techniques used for the data analysis was: descriptive statistics, factorial analysis and modeling of structural equations. Initially it is necessary to identify the profile of the sample. The sample was composed mainly for men $(53.8 \%)$, with some superior formation $(71.8 \%)$, with age between 18 and 29 years $(55.1 \%)$ and with average income between 6 and 10 minimum wages (27.2\%). With regard to the daily time of connection with the Internet, it was observed that the majority of the searched ones is up to 4 daily hours connected $(51 \%)$.

The next stage consisted of carrying through a confirmatory factorial analysis with the used scales. Due to the sample size, Hair et al. [17] indicate that items with factorial load below 0.400 must be excluded from the analysis.

The first analyzed scale is relative to the perceived risk. The gotten KMO was equal to 0.853 , qui-square of $477.663,21$ degrees of freedom and significance 0.000 . The summary of the analysis can be observed in Table 3. An item was excluded because it not presenting significant factorial load.

The next scale is regarding to the flow. The gotten $\mathrm{KMO}$ was equal the 0.469 , qui-square of $14.078,6$ degrees of freedom and significance 0.029 . The result of this analysis can be observed in Table 4. Excessively items had been excluded to get one significant cronbach's alpha or because they had not gotten the demanded minimum factorial load.

Last scale is regarding to the ability. The gotten KMO was equal the 0.807 , qui-square of $1399.647,190$ degrees of freedom and significance 0.000 . The result of this analysis can be observed in Table 5 .

Several items had been excluded because they had not gotten the demanded minimum factorial load.

From the factorial analyses, 03 latent factors had been identified: Risk, Flow and Abilities. This variable will be the base to construct the path diagram tested in the structural equations modeling. The following item presents the structural equations modeling.

\section{Structural Equation Modeling}

A basic characteristic of the structural equations modeling is the possibility to test a theory of causal order between a set of variables. In such a way, the technique proposal offers to the researcher the possibility to investigate the dependent variable in such a way as independent [18].

The technique also adopted allows calculating props up them factorials for the latent variable, what it is possible when the cases for the calculation of the model are used directly. Two types of variable in a model (path diagram) of structural equations modeling exist: endogenous and exogenous variables.

The values of the endogenous variable are explained by one or more endogenous variables of the model. The values of the exogenous variable are assumed as given, that is, the model does not try to explain them. This distinction is similar to the made one between dependent variable (endogenous) and independent (exogenous) of the regression analysis [17].

Path diagram tested here can be visualized on Picture 1. The observed indices of adjustment (fit)-CFI (0.913) and RMSEA (0.061)-are valid [17]. These indices measure the internal consistency of the model.

Table 6 summarizes the main relations observed in the model.

We observed that hypothesis 1 was confirmed, therefore with a significance of 0.000 is possible to conclude that the ability influences in the perceived risk of the consumers of e-commerce. The second hypothesis was rejected. According the structural equations modeling there is no significant relationship between the flow and the perceived risk. The next topic presents the conclusions of the study.

\section{Conslusions}

Analysis has showed that the relation indicated on Hypothesis 1 was confirmed. This result confirms Koufaris 
Table 3. Perceived risk factorial analysis.

\begin{tabular}{ccc}
\hline Item & Factor (Risk) & Cronbach's Alpha \\
\hline Not receive the product & 0.812 & \\
Not receive in the stated period & 0.775 & 0.730 \\
Improper debit on credit card & 0.763 \\
Receive a false product & 0.755 & \\
Invasion in the computer & 0.715 \\
Loss of Privacy & 0.692 \\
No risk perceived & -0.412 \\
\hline
\end{tabular}

Table 4. Flow state factorial analysis.

\begin{tabular}{ccc}
\hline Item & Factor (Ability) & Cronbach's Alpha \\
\hline Not Interested & -0.764 & \\
Relax & -0.750 & 0.609 \\
Glad & 0.506 & \\
Attention & 0.467 & \\
\hline
\end{tabular}

Table 5. Flow dimensions factorial analysis.

\begin{tabular}{|c|c|c|}
\hline Item & $\begin{array}{l}\text { Factor } \\
\text { (Fluxo) }\end{array}$ & $\begin{array}{c}\text { Cronbach's } \\
\text { Alpha }\end{array}$ \\
\hline After using web, I feel like I come back to the "real world" after a journey. & 0.783 & \multirow{14}{*}{0.777} \\
\hline Using the web often makes me forget where I am. & 0.734 & \\
\hline Using the web creates a new world for me and this world suddenly disappears when I stop browsing. & 0.717 & \\
\hline Using the web provides a good test of my skills. & 0.635 & \\
\hline When I use the web, my body is in the room, but my mind is inside the world created by websites I visit. & 0.628 & \\
\hline When I use the web, the world generated by the sites I visit is more real for me than the "real world". & 0.622 & \\
\hline I forget about my immediate surroundings when I use the web. & 0.610 & \\
\hline When I use the web, I feel I am in a world created by the websites I visit. & 0.572 & \\
\hline When I use the web, I tend to lose track of time. & 0.568 & \\
\hline I find that using the web stretches my capabilities to my limits. & 0.560 & \\
\hline Time seems to go by very quickly when I use the web. & 0.497 & \\
\hline Using the web challenges me. & 0.466 & \\
\hline Using the web challenges me to perform to the best of my ability. & 0.444 & \\
\hline I consider myself knowledgeable about good search techniques on the web. & -0.418 & \\
\hline
\end{tabular}

Table 6. Estimative.

\begin{tabular}{cccc}
\hline Relationships & Estimative & DE & Sig. \\
\hline Risk $\leftarrow \rightarrow$ Flow & 0.033 & 0.170 & 0.844 \\
Risk $\rightarrow$ Ability & 2.520 & 0.404 & 0.000 \\
Flow $\rightarrow$ Ability & 0.023 & 0.118 & 0.846 \\
\hline
\end{tabular}




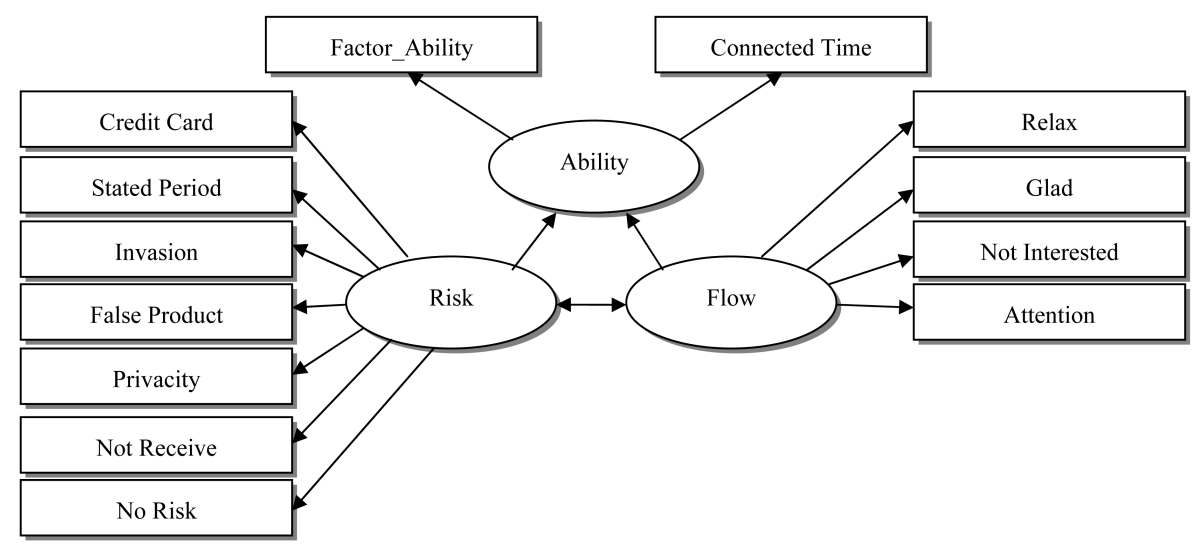

Picture 1. Path diagram.

[1], Bhatnagar and Ghose [3], Doolin et al. [14] ideas. It indicates that the more the individuals buy for the Internet, the more ability they will have.

Regarding Hypothesis 2, the perception of manipulated risk diminishes the occurrence of the flow state during the purchase process on-line. In such a way, the result of the analyses demonstrated that the perceived risk does not have relation with the state of flow of the consumer.

This information disconstructs the positioning of Dailey [15], Delespaul et al. [12], Mathwick and Rigdon [13] and Smith and Sivakumar [6], about the correlation of perceived risk and flow state.

Other authors had also studied the relation between the perceived risk and the state of flow. Ghani and Deshpande [19] and Koufaris [1] consider that the risk perception tends to inhibit the state of flow because of the negative emotions evokes (anxiety and fear) that can make the consumer give up the purchase.

Another hypothesis is that low perception of risk increases the probabilities to occur the flow state [14]. For these two cases, the existence of the perceived risk could inhibit the presence of the flow, therefore negative feelings enter in contradiction with the positive feelings of the state of flow, as diversion and pleasure and, the less the consumer perceive the risk, the higher would be the possibilities to occur the flow.

\section{References}

[1] Koufaris. M. (2002) Applying the Techonology Acceptance Model and Flow Theory to Online Consumer Behavior. Informations System Research, 13.

[2] Elliot, M.T. and Speck, P. (2005) Factors That Affect Attitude toward a Retail Web Site. Journal of Marketing Theory and Practice, 13, 40.

[3] Bhatnagar, A. and Ghose, S. (2004) Segmenting Consumers Based on the Benefits and Risks of Internet Shopping. Journal of Business Research, 57. http://dx.doi.org/10.1016/S0148-2963(03)00067-5

[4] Csikszentmihalyi, M. (1977) Beyond Boredom and Anxiety. Jossey-Bass, San Francisco.

[5] Hoffman, D.L. and Novak, T.P. (1996) Marketing in Hypermedia Computer-Mediated Environments: Conceptual Foundations. Journal of Marketing, 60, 50-68.

[6] Smith, D.N. and Sivakumar, K. (2004) Flow and Internet Shopping Behavior: A Conceptual Model and Research Propositions. Journal of Business Research, 57, 1199-1208.

[7] Lasch, E. (1998) Do You Trust the Web? Ohio CPA Journal, 57.

[8] Larson, D.A., Engelland, B. and Taylor, R. (2004) Information Search and Perceived Risk: Are There Differences for In-Home versus In-Store Shoppers? The Marketing Management Journal, 14, 36-42.

[9] Rohm, A.J. and Milne, G.R. (1998) Emerging Marketing and Policy Issues in Eletronic Commerce: Attitudes and Beliefs of Internet Users. Marketing and Public Policy Proceedings, 8.

[10] Novak, T.P., Hoffman, D.L. and Yung, Y. (2000) Measuring the Customer Experience in Online Environments: A Structural Modeling Approach. Marketing Science, 19, 22-42. http://dx.doi.org/10.1287/mksc.19.1.22.15184

[11] Shih, C. (1998) Conceptualizing Consumer Experiences in Cyberspace. European Journal of Marketing, 32.

[12] Delespaul, P.A., Reis, H.T. and Devries, M.W. (2004) Ecological and Motivational Determinants of Activation: Studying Compared to Sports and Watching TV. Social Indicators Research, 67, 129-143. 
http://dx.doi.org/10.1023/B:SOCI.0000007337.94184.e5

[13] Mathwick, C. and Rigdon, E. (1998) Play, Flow, and the Online Search Experience. Journal of Consumer Research, 31, 324-332.

[14] Doolin, B., Dillon, S., Thompson, F. and Corner, J.L. (2005) Perceived Risk, the Internet Shopping Experience and Online Purchasing Behavior: A New Zealand Perspective. Journal of Global Information Management, 13. http://dx.doi.org/10.4018/jgim.2005040104

[15] Dailey, L. (2004) Navigational Web Atmospherics: Explaining the Influence of Restrictive Navigation Cues. Journal of Business Research, 57, 795-803. http://dx.doi.org/10.1016/S0148-2963(02)00364-8

[16] Babbie, E. (2001) Métodos de pesquisas de survey. UFMG, Belo Horizonte.

[17] Hair, J.F., Black, W.C., Babin, B.J., Anderson, R.E. and Tatham, R.L. (2006) Multivariate Data Analysis. 6th Edition, Prentice Hall, New Jersey.

[18] Maruyama, G.M. (1998) Basics of Strutural Equation Modeling. Sage, Thousand Oaks.

[19] Ghani, J.A. and Deshpande, S.P. (1994) Task Characteristics and the Experience of Optimal Flow in Human-Computer Interaction. Journal of Psychology, 128, 381-391. 